\title{
COMPOSITION OF RABBIT OVIDUCT FLUID IN LIGATED SEGMENTS OF THE FALLOPIAN TUBE
}

\author{
A. DAVID*, B. G. BRACKETT, G-R. GARGIA \\ AND L. MASTROIANNI, JR \\ Division of Reproductive Biology, Department of Obstetrics and Gynecology, \\ University of Pennsylvania School of Medicine, Philadelphia, Pennsylvania, U.S.A.
}

(Received 18th Fune 1968, revised 29th November 1968)

\begin{abstract}
Summary. Forty-six, mature, New Zealand white does were used for collection of fluid from the Fallopian tubes. Ligation of the tubes into four isolated segments was carried out with minimal disturbance to the blood supply, using an operating microscope. The volume of fluid collected decreased from the fimbriated end to the utero-tubal junction.

Analysis of the chemical constituents of the fluid from the first three segments showed that the concentration of sodium, bicarbonate, inorganic phosphate, proteins and lactic acid increased significantly from the fimbriated end to the utero-tubal junction, while chloride concentration decreased significantly. These results support the possibility that the different segments of the oviduct may play specific roles in early events of reproduction.
\end{abstract}

\section{INTRODUCTION}

Since the studies of Woskressensky in 1891, attention has been directed to the secretory activity of the mammalian oviduct. Previous investigations (Bishop, 1956; Mastroianni, Forrest \& Winterwitz, 1961 ; Mastroianni \& Ehteshamzadeh, 1964; Hamner \& Williams, 1963, 1964) were concerned with the chemical composition of fluid accumulations in the entire oviduct. No attempts were made to correlate the fluid content with the anatomical and histological variations existing from the fimbriated end to the utero-tubal junction (Nilsson \& Reinus, 1968).

In this study, some chemical constituents were measured in the intraluminal fluid obtained from ligated segments of the oviduct.

\section{MATERIALS AND METHODS}

Forty-six, mature, New Zealand white female rabbits $(3.5$ to $5.2 \mathrm{~kg}$ ) were used. Each animal had been isolated in a separate cage for at least 18 days. Does

* Ford Foundation Research Fellow. Permanent address: Tel-Hashomer Hospital, Tel-Aviv Medical School, Israel. 
were anaesthetized with intravenous pentobarbital sodium and the abdomen was entered through a mid-line incision. Ovaries were inspected and only rabbits with ovarian follicles and no evident corpora lutea were used.

Each oviduct was ligated into four segments. The segments were demarcated macroscopically following the description of Greenwald (1961) with slight modifications (Gupta, Karkun \& Kar, 1967). The first segment included the ampulla immediately proximal to the fimbria to a point about $1 \mathrm{~cm}$ from the narrower portion where the isthmus begins. The second segment, defined as the ampullary-isthmic portion, included the end of the wider portion of the ampulla and the first part $(1.0$ to $1.5 \mathrm{~cm})$ of the narrower isthmus. The third segment included the mid-portion of the isthmus to within 1.0 to $1.5 \mathrm{~cm}$ of the uterine horn. The fourth segment consisted of the remainder of the isthmus to the utero-tubal junction. Ligations were carried out with the aid of a Zeiss operating microscope, with Barraquer modification, at a magnification of $\times 10$ to $\times 25$. Silk $(6-0)$ or nylon $(8-0)$ suture material mounted on an atraumatic needle was used to ligate each segment. The sutures were placed beneath the principal vessels to avoid interfering with the vascularity of the oviducts. By this microsurgical technique, the tube was segmented with minimal disturbance to the blood supply. In some animals the oviducts were ligated bilaterally, while in others only one side was used. Long-acting penicillin $G$ suspension (150,000 i.u. benzathine) was given intramuscularly after the operation was completed. Accumulated fluid was collected 3 days after ligation by aspiration of each segment with a $2.5 \mathrm{ml}$ syringe using a 25 -gauge needle. Samples with the slightest contamination of blood were discarded. At this time the ovaries were re-examined. In no instance was there evidence of ovulation. The volume and $\mathrm{pH}$ of the fluid recovered from each segment were recorded immediately and the fluid was stored individually in sealed Pyrex vials. When chemical analysis could not be done immediately, the fluid was preserved at 2 to $4^{\circ} \mathrm{C}$.

Sodium, potassium and calcium were determined with a flame photometer (Instrumentation Laboratory, Model 142), chloride by a Cotlove Chloratometer (Cotlove, Tranthum \& Bowman, 1958), magnesium and zinc by an atomic absorption spectrophotometer (Model 303, Perkin Elmer) and inorganic phosphate was determined by the method of Fiske \& Subbarow (1925). A Natelson (1951) microgasometer was used to determine bicarbonate content, 30 lambda of fluid being required for each assay. Barker \& Summerson's method (1941) was used for lactic acid determinations. Total proteins were determined by a modified biuret method. Dry matter was determined after the oviduct fluid had been kept at $105^{\circ} \mathrm{C}$ for $4 \mathrm{hr}$. The amounts of each constituent in the segments were compared and tested for statistical significance by the homogeneity $\chi^{2}$ test and Student's $t$ test (Fisher, 1958).

\section{RESULTS}

Fluid was obtained from sixty-one oviducts of forty-six rabbits and the amount recovered from each segment 3 days after ligation was measured (Table 1). Since only minute quantities of fluid $(0.027 \pm 0.022 \mathrm{ml})$ could be recovered from Segment 4, further work with this fluid was not feasible. The $\mathrm{pH}$ range 
was 7.32 to 8.05 for Segment 1; 7.90 to 8.20 for Segment 2; and 7.79 to 7.87 for Segment 3.

Sodium concentrations were significantly lower in Segment 1 than in Segments 2 and $3(P<0 \cdot 05)$; less difference was found between Segments 2 and 3 $(P=0 \cdot 05)$. Chloride showed a significant decrease between Segments 1 and 3 $(P<0.01)$; but not between Segments 2 and $3(P=0.05)$. Bicarbonate levels were significantly higher in Segment 3 than in Segment $1(P<0.01)$ but not between Segments 3 and $2(P=0.05)$. There was no significant variation in bicarbonate between Segments 1 and 2. Inorganic phosphate concentrations were significantly higher in Segments 2 and 3 than in $1(P<0 \cdot 05)$; there was

TABLE 1

BIOCHEMICAL COMPOSITION OF RABBIT SEGMENTAL OVIDUCT FLUID

\begin{tabular}{|c|c|c|c|}
\hline Constituents & $\begin{array}{l}\text { Segment } 1 \\
\text { (ampulla) }\end{array}$ & $\begin{array}{c}\text { Segment } 2 \\
\text { (ampullary- } \\
\text { isthmic region) }\end{array}$ & $\begin{array}{c}\text { Segment } 3 \\
\text { (isthmus) }\end{array}$ \\
\hline $\begin{array}{l}\text { Volume of fluid (ml)* } \\
\text { Sodium (m-equiv./1) } \\
\text { Chloride (m-equiv./1) } \\
\text { Potassium (m-equiv./1) } \\
\text { Bicarbonate (m-equiv./1) } \\
\text { Calcium (mg/100 ml) } \\
\text { Total protein (mg/100 ml) } \\
\text { Magnesium (mg/100 ml) } \\
\text { Zinc (mg/100 ml) } \\
\text { Dry matter (mg/ml) } \\
\text { Inorganic phosphate }(\mu \mathrm{g} / \mathrm{ml}) \\
\text { Lactic acid ( } \mu \mathrm{g} / \mathrm{ml})\end{array}$ & $\begin{array}{r}1 \cdot 15 \pm 0.53(59) \\
141 \cdot 87 \pm 1.68(12) \\
119.25 \pm 3.49(12) \\
6.45 \pm 1.25(14) \\
27.52 \pm 2.93(15) \\
11.00 \pm 5.68(6) \\
77.92 \pm 42.62(13) \\
0.30 \pm 0.16(12) \\
0.01 \pm 0(6) \\
12.68 \pm 0.14(5) \\
3.41 \pm 1.44(10) \\
34.36 \pm 15.18(11)\end{array}$ & 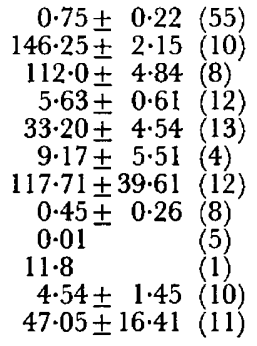 & $\begin{aligned} & 0.32 \pm 0.10(55) \\
& 148.25 \pm 3.43(8) \\
& 101.0 \pm 4.86(6) \\
& 4.75 \pm 0.57(8) \\
& 41.34 \pm 4.45(10) \\
& 10.87 \pm 4.09(4) \\
& 135.72 \pm 26.45(9) \\
& 0.40 \pm 0.17(6) \\
& 0.01(4) \\
& 10.9(1) \\
& 4.76 \pm 1.59(7) \\
& 64.78 \pm 38.95(8)\end{aligned}$ \\
\hline
\end{tabular}

Values are mean \pm S.D.; figures in parentheses represent numbers of segments used.

* Fluid accumulated 3 days after ligation.

no difference between Segments 2 and 3. Lactic acid concentrations were significantly higher in Segments 2 and 3 than in Segment $1(P<0.05)$; the difference between Segments 2 and 3 was within the limit of statistical significance $(P=0 \cdot 05)$. Protein concentrations were significantly higher in Segments 2 and 3 than in Segment $1(P<0.04$ and $P<0.02$, respectively $)$. There was no significant difference between Segments 2 and 3. The concentrations of potassium, calcium, magnesium and zinc were not significantly different among the segments.

\section{DISCUSSION}

Ligation of the oviducts into segments involving the ampulla, the ampullaryisthmic region and the isthmus was followed by distension of each segment by fluid. Distension was less pronounced in the thicker, isthmic portion of the oviduct.

Differences in the volume of fluid accumulation in the various segments may be explained by histological variations of the epithelium of oviduct segments. A decreasing number of secretory cells from the ampulla to the isthmus has been observed by others (Nilsson \& Reinus, 1968; Gupta et al., 1967). One must, however, take into account the increased thickness of the muscular wall in the isthmus, which might, through increased resistance, modify the secretory rate. 
Assuming that the amount of fluid in each segment accumulates uniformly throughout the 3 days after ligation, one can estimate the daily oviduct fluid production by each segment. The 24-hr production of oviduct fluid by Segment 1 would be 0.14 to $0.63 \mathrm{ml}$; Segment 2, 0.06 to $0.43 \mathrm{ml}$; Segment 3, 0.05 to 0.17 $\mathrm{ml}$; and by Segment 4, from 0.016 to $0.02 \mathrm{ml}$. The $24-\mathrm{hr}$ secretion rate for the entire oviduct would range from 0.25 to $1.25 \mathrm{ml}$. The maximal rate approximates to the total volumes reported by others (Bishop, 1956; Mastroianni \& Wallach, 1961; Hamner \& Williams, 1965). The $\mathrm{pH}$ values were comparable to those previously reported for oviduct fluids although slightly lower than has been observed in fluid collected continuously (Vishwakarma, 1962; Mastroianni \& Ehteshamzadeh, 1964; Hamner \& Williams, 1965). This probably reflects loss of $\mathrm{CO}_{2}$ in the collecting flasks used by these authors. In the present study, the method of collection did not preclude initial contact with air and thus the bicarbonate content may have been somewhat reduced. The fluid removed from each segment was handled in an identical way, however, permitting valid comparison of the values obtained.

The concentrations of sodium and bicarbonate varied inversely with that of chloride. There was an increase in sodium and a decrease in chloride from Segments 1 to 3, with an increase in bicarbonate from Segments 1 to 3 .

Tubal fluid is credited with a passive role in protecting the gametes and facilitating their transport through the oviducts. It is also capable of contributing to the denudation of the densely arranged corona radiata cells surrounding recently ovulated ova in the rabbit. The bicarbonate ion is responsible for this denudation effect (Mastroianni \& Ehteshamzadeh, 1964; Stambaugh, Noriega \& Mastroianni, 1969). This study shows that the bicarbonate concentrations increase from Segments 1 to 3. In vivo, rabbit ova become denuded as they pass through Segments 2 and 3. Rabbit oviduct fluid causes an increase in oxygen uptake of spermatozoa in vitro, whereas bicarbonate ions in lower concentrations than those found in oviduct fluid, are the major stimuli to the increased uptake of oxygen by rabbit spermatozoa in vitro (Hamner \& Williams, $1963,1964)$. Since bicarbonate has been shown to affect sperm metabolism, the higher range of bicarbonate values in Segments 2 and 3 may be related to the capacitation process.

Lactic acid, which increased in concentration from Segments 2 to 3, probably serves as a source of energy for the early cleavage of the fertilized egg (LutwakMann, 1962; Brinster, 1965) or as a metabolic substrate used by spermatozoa in aerobic conditions (Holmdahl \& Mastroianni, 1965).

The rise in inorganic phosphate concentration from Segments 1 to 3 seems to correlate with the fact that the inclusion of phosphate, mainly as a buffer, is essential for good motility and a stable metabolic rate in mammalian sperm suspensions. Total protein concentrations, which increase from Segments 1 to 2 and 2 to 3 , may be of importance to the recently-fertilized ovum for it has been shown that such ova may incorporate more proteins than unfertilized ova (Greenwald \& Everett, 1959; Fredricsson, 1968). Moreover, it was found (Wales \& White, 1963) that the viability of diluted dog spermatozoa depends on the presence of protein, which appears to overcome the harmful effects of dilution, motility being maintained as in a concentrated suspension. 
The chemical composition of the oviduct tissue has been shown to vary from segment to segment (Gupta et al., 1967); the histology of the oviduct has also been shown to vary segmentally. From the present study, it is concluded that the composition of the fluid produced by the oviduct also differs in its various segments suggesting that these segments may play specific roles in the early events of reproduction.

\section{ACKNOWLEDGMENTS}

This work was supported by a research grant from the Ford Foundation. The authors wish to express their thanks for the technical assistance of Mrs Eva Kelly, Mrs Linda Enck and Mr James Butler.

\section{REFERENCES}

BARKer, S. B. \& SUMmerson, W. H. (1941) The colorimetric determination of lactic acid in biological material. F. biol. Chem. 138, 535.

Bishop, D. W. (1956) Active secretion in rabbit oviduct. Am. 7. Physiol. 187, 347.

BRINSTER, R. L. (1965) Studies on the development of mouse embryos in vitro. IV. Interaction of energy sources. J. Reprod. Fert. 10, 227.

Cotlove, E., Tranthum, H. V. \& Bowman, R. L. (1958) An instrument and method for automatíc, rapid, accurate and sensitive titration of chlorides in biological samples. F. Lab. clin. Med. 50, 358.

Fisher, R. A. (1958) Statistical methods for research workers. Oliver \& Boyd, Edinburgh.

Fiske, C. A. \& Subbarow, Y. (1925) The colorimetric determination of phosphorus. 7. biol. Chem. 66, 375.

Fredricsson, B. (1968) Histochemistry of the oviduct. In: The Mammalian Oviduct. Eds. E. S. E. Hafez and R. G. Blandau. University of Chicago Press.

GREenWALd, G. S. (1961) A study of the transport of ova through the rabbit oviduct. Fert. Steril. 12, 80.

Greenwald, G. S. \& Everetr, N. B. (1959) The incorporation of $\mathrm{S}^{35}$ methionine by the uterus and ova of the mouse. Anat. Rec. 134, 171 .

Gupta, D. N., Karkun, J. N. \& Kar, A. B. (1967) Biochemical composition of different portions of rabbit fallopian tube. Indian F. exp. Biol. 5, 124.

Hamner, C. E. \& Williams, W. L. (1963) Effect of the female reproductive tract on sperm metabolism in the rabbit and fowl. 7. Reprod. Fert. 5, 143.

Hamner, C. E. \& Williams, W. L. (1964) Identification of sperm stimulating factor of rabbit oviduct fluid. Proc. Soc. exp. Biol. Med. 117, 240.

Hamner, G. E. \& Williams, W. L. (1965) Composition of rabbit oviduct secretions. Fert. Steril. 16, 170.

HolmdahL, T. H. \& Mastrolann, L., JR (1965) Continuous collection of rabbit oviduct secretions at low temperature. Fert. Steril. 16, 587.

Lutwak-ManN, C. (1962) Glucose, lactic acid and bicarbonate in rabbit blastocyst fluid. Nature, Lond. $193,653$.

Mastroianni, L. \& Ehteshamzadeh, J. (1964) Corona cell dispersing properties of rabbit oviductal fluid. F. Reprod. Fert. 8, 145.

Mastrolanni, L., Forrest, W. \& Winterwitz, W. W. (1961) Some metabolic properties of the rabbit oviduct. Proc. Soc. exp. Biol. Med. 107, 86.

Mastrolanni, L. \& Wallach, R. G. (1961) Effect of ovulation and early gestation on oviduct secretions in the rabbit. Am. J. Physiol. 200, 815.

Natelson, S. (1951) Routine use of ultra micro methods in the clinical laboratory. Am. F. clin. Path. 21, 1153.

Nizsson, O. \& ReInus, S. (1968) Light and electron microscopic structure of the oviduct. In: The Mammalian Oviduct. Eds. E. S. E. Hafez and R. G. Blandau. University of Chicago Press.

Stambaugh, R., Noriega, C. \& Mastroianni, L. (1969) Bicarbonate ion; the corona cell dispersing factor of rabbit tubal fluid. F. Reprod. Fert. 18, 51 .

Vishwakarma, P. (1962) The pH and bicarbonate-ion content of the oviduct and uterine fluids. Fert. Steril. 13, 481.

WALES, R. G. \& White, I. G. (1963) Viability of dilute dog spermatozoa in vitro. J. Reprod. Fert. 5, 67.

Woskressensky, M. A. (1891) Experimentelle Untersuchungen über die Pyo und Hydrosalpinx bildung bei den Tieren. Zentbl. Gynäk. 15, 849. 